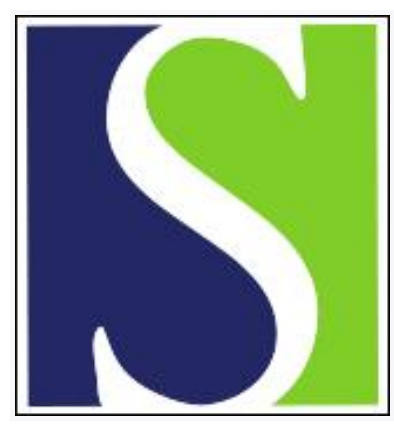

Scand J Work Environ Health 1977;3(4):192-202

https://doi.org/10.5271/sjweh.2773

Issue date: Dec 1977

Urinary chromium as an indicator of the exposure of welders to chromium.

by Tola S, Kilpiö J, Virtamo M, Haapa K

Key terms: biological exposure test; chromium; exposure; urinary chromium; welder; welding

This article in PubMed: www.ncbi.nlm.nih.gov/pubmed/594727

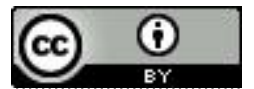




\title{
Urinary chromium as an indicator of the exposure of welders to chromium
}

\author{
by SAKARI TOLA, M.D., ${ }^{1}$ JUKKA KILPIÖ, M.Sc., ${ }^{1}$ MATTI VIRTAMO, M.Sc., ${ }^{1}$ \\ and KAUKO HAAPA, M.D. ${ }^{2}$
}

\begin{abstract}
TOLA, S., KILPIÓ, J., VIRTAMO, M. and HAAPA, K. Urinary chromium as an indicator of the exposure of welders to chromium. Scand. $j$. work environ. \& health 3 (1977) 192-202. Five welders working with high alloy $\mathrm{Cr}-\mathrm{Ni}$ steel and one working with mild steel were followed during one work week. The chromium concentration in air was measured concomitantly with urinary chromium determinations. The water-soluble chromium concentrations in air exceeded $0.05 \mathrm{mg} / \mathrm{m}^{3}$ during welding with coated electrodes, but metal inert-gas (MIG) welding produced much lower concentrations. The proportion of water-soluble hexavalent chromium in the air was usually more than $50 \%$ of the total chromium concentration during welding with coated electrodes, whereas less than $10 \%$ of the chromium produced during MIG welding was in a water-soluble form. Since water-soluble chromium (hexavalent) is the more important biologically, the determination of both water-soluble and waterinsoluble chromium concentrations is emphasized instead of the measurement of the total concentration. The urinary chromium concentration proved to be a good indicator of short-term exposure to water-soluble chromium when exposure was above the current threshold limit value of $0.05 \mathrm{mg} / \mathrm{m}^{3}$, concentrations of more than $30 \mu \mathrm{g} / \mathrm{g}$ of creatinine representing an exposure level higher than the threshold limit value.
\end{abstract}

Key words: biological exposure tests, chromium, welding.

Chromium ( $\mathrm{Cr}$ ) is known to have various deleterious effects upon the human organism $(7,8,31)$. Usually such effects are due to the hexavalent (VI) form of the element, but trivalent (III) chromium also appears to play a role, at least in connection with skin sensitization (14). Chromium has an irritative effect on skin and mucous membranes. For example chromium ulcers and nasal septal perforations have been frequent findings in workers exposed to chromic acid or chromates $(9,19,25,26)$. Allergic eczema as a result of sensitization to chromium is also well recognized $(2,13$,

1 Institute of Occupational Health, Helsinki, Finland.

2 A. Ahlström Oy, Karhula, Finland.

Reprint requests to: Dr. Sakari Tola, Institute of Occupational Health, Haartmaninkatu 1, SF-00290 Helsinki 29, Finland.
$14,24,29,32)$. Sensitization may also affect the respiratory organs and cause asthma (8). In connection with heavy exposure to chromium gastrointestinal symptoms have been reported (36). The most serious effect however is its ability to cause cancer in $\operatorname{man}(3,4,11,18,22)$.

Before exposure to chromium can be effectively limited, reliable methods of measuring the exposure are needed. The determination of chromium in the workroom air is a reasonably good measure of chromium exposure, and threshold limit values (TLVs) for various chromium compounds provide a basis for practically evaluating the results $(8,30,37)$. For the assessment of individual exposure a biological exposure test would provide additional information or even an alternative to workroom air measurements. The concentration of chromium in blood and urine 
can be measured, but there is a lack of well-controlled studies on the relationship between exposure and biological indicators. Moreover, the oxidation state of chromium in the air, whether tri- or hexavalent, has not been reported often. Nevertheless, maximum allowable concentrations have been proposed for urinary chromium concentrations $(12,15,35,36,37)$. Too few data exist to allow evaluations of blood chromium measurements, but at present they seem to be of little or no value to biological exposure testing.

Borghetti et al. (6) recently published results of a longitudinal study in which they showed qualitative evidence in favor of a relationship between exposure to chromium and urinary chromium excretion. Shortly before we submitted this paper for publication, Gylseth et al. (15) published a study similar to ours in which a good correlation between chromium in air and urinary chromium excretion was demonstrated. In our report we present the results of a one-week follow-up study of welders exposed to chromium during the welding of high alloy $\mathrm{Cr}-\mathrm{Ni}$ steel.

\section{SUBJECTS AND EXPOSURE}

The study subjects were healthy male welders with a mean age of 27.5 years (range 21-34). Their mean working time as welders was 8.8 years (range $4-16$ ). They had all welded both mild steel and high alloy $\mathrm{Cr}-\mathrm{Ni}$ steel during previous years. During the study week, all except the control subject welded high alloy $\mathrm{Cr}$ Ni steel. Four of them (A, B, C, D) welded with coated electrodes and one (E) did metal inert-gas (MIG) welding. The control subject (F) welded only mild steel with basic electrodes during the study week. One of the study subjects (B) also welded mild steel on three workdays (Wednesday afternoon, all day Thursday, and Friday all day but alternately with the welding of high alloy $\mathrm{Cr}-\mathrm{Ni}$ steel).

The welders' regular daily worktime was $8 \mathrm{~h}$, of which they either welded or did assembly work in connection with welding for some $6-7 \mathrm{~h}$.

The workplace was a shop where machines for the pulp and paper industry were manufactured. The assembly shop had an area of $5,000 \mathrm{~m}^{2}$ and a room size of 50,000 $\mathrm{m}^{3}$. It was equipped with dilution ventilation with blowing and exhausting of $150,000 \mathrm{~m}^{3} / \mathrm{h}$, but no local exhaust systems were used at the welding sites. All welding work was done in open air conditions.

The metals welded were high alloy Cr$\mathrm{Ni}$ steel, containing $18 \%$ chromium, and mild steel, in which chromium was present only as an impurity $(<0.3 \% \mathrm{Cr})$. The electrode wire for the MIG welding contained $20 \%$ chromium. The coated electrodes for the chromium steel were of the rutile type. The core wires of the coated electrodes contained 18-20\% chromium; and the coatings, ferrochromium corresponding to $12-20 \%$ of elemental chromium. In the welding electrodes for mild steel chromium appeared only as an impurity.

\section{METHODS}

Air and urine samples were collected during one work week. The urine samples were taken from every subject at 0700 , 1100 , and 1600 everyday of the week plus the previous Friday at 1600 and the following Monday at 0700. Air samples were collected each morning and afternoon on Monday through Friday except for the control subject, for whom they were taken on Tuesday and Thursday only. Blood samples were also collected, but only on Monday at 0700 and Tuesday at 0700 and 1600.

\section{Welding fume measurements}

Sampling. The welding fume samples were collected on cellulose ester membrane filters (Millipore Filter AAWP $ø 37 \mathrm{~mm}$, mean pore size $0.8 \mu \mathrm{m}$ ) with personal sampling pumps (Rothroe \& Mitchell Portable Dust Sampler L2C and MSA Monitaire Sampler Pump, Model S).

All samples were taken from the breathing zone, the filter holder being placed inside of the welder's face mask. Each sampling pump and membrane filter combination was calibrated against a wet gas meter. Flow rates averaged $1.7 \mathrm{1} / \mathrm{min}$ for the MSA samplers and $2.5 \mathrm{l} / \mathrm{min}$ for the Rothroe \& Mitchell pumps. Sampling times 
Table 1. Total fume and chromium concentrations in workroom air collected with personal samplers for six welders during the study week.

\begin{tabular}{|c|c|c|c|c|c|c|c|}
\hline \multirow{3}{*}{ Subject } & \multirow{3}{*}{$\begin{array}{l}\text { Sampling } \\
\text { day }\end{array}$} & \multirow{3}{*}{$\begin{array}{l}\text { Total fume } \\
\left(\mathrm{mg} / \mathrm{m}^{3}\right)\end{array}$} & \multicolumn{3}{|c|}{ Water-soluble chromium } & \multirow{3}{*}{$\begin{array}{l}\text { Acid-soluble } \\
\text { chromium } \\
\left(\mathrm{mg} / \mathrm{m}^{3}\right)\end{array}$} & \multirow{3}{*}{$\begin{array}{c}\text { Total } \\
\text { chromium } \\
\left(\mathrm{mg} / \mathrm{m}^{3}\right)\end{array}$} \\
\hline & & & \multirow{2}{*}{$\begin{array}{l}\text { DPC method } \\
\text { Cr }(\mathrm{VI}) \\
\left(\mathrm{mg} / \mathrm{m}^{3}\right)\end{array}$} & \multicolumn{2}{|c|}{ AAS method } & & \\
\hline & & & & $\mathrm{mg} / \mathrm{m}^{3}$ & $\begin{array}{c}\% \% \text { of } \\
\text { total } \mathrm{Cr} a\end{array}$ & & \\
\hline A & $\begin{array}{l}\text { Mon. } \\
\text { Tues. } \\
\text { Wed. } \\
\text { Thurs. } \\
\text { Fri. }\end{array}$ & $\begin{array}{c}12 \\
13 \\
7.7 \\
9.1 \\
8.0\end{array}$ & $\begin{array}{l}0.51 \\
0.36 \\
0.18 \\
0.18 \\
0.18\end{array}$ & $\begin{array}{l}0.52 \\
0.39 \\
0.18 \\
0.21 \\
0.19\end{array}$ & $\begin{array}{l}89 \\
85 \\
70 \\
84 \\
74\end{array}$ & $\begin{array}{l}0.07 \\
0.10 \\
0.07 \\
0.04 \\
0.07\end{array}$ & $\begin{array}{l}0.58 \\
0.45 \\
0.25 \\
0.25 \\
0.25\end{array}$ \\
\hline B & $\begin{array}{l}\text { Mon. } \\
\text { Tues. } \\
\text { Wed. } \\
\text { Thurs. } \\
\text { Fri. }\end{array}$ & $\begin{array}{l}3.9 \\
8.1 \\
5.8 \\
4.1 \\
4.7\end{array}$ & $\begin{array}{l}0.04 \\
0.19 \\
0.33 \\
0.00^{b} \\
0.04\end{array}$ & $\begin{array}{l}0.05 \\
0.12 \\
0.39 \\
0.004 \\
0.05\end{array}$ & $\begin{array}{l}44 \\
75 \\
92 \\
12 \\
47\end{array}$ & $\begin{array}{l}0.06 \\
0.10 \\
0.09 \\
0.03 \\
0.06\end{array}$ & $\begin{array}{l}0.10 \\
0.28 \\
0.42 \\
0.03 \\
0.10\end{array}$ \\
\hline C & $\begin{array}{l}\text { Mon. } \\
\text { Tues. } \\
\text { Wed. } \\
\text { Thurs. } \\
\text { Fri. }\end{array}$ & $\begin{array}{c}6.3 \\
11 \\
8.0 \\
6.4 \\
6.6\end{array}$ & $\begin{array}{l}0.13 \\
0.29 \\
0.18 \\
0.13 \\
0.14\end{array}$ & $\begin{array}{l}0.16 \\
0.26 \\
0.20 \\
0.16 \\
0.15\end{array}$ & $\begin{array}{l}92 \\
64 \\
68 \\
92 \\
78\end{array}$ & $\begin{array}{l}0.05 \\
0.11 \\
0.12 \\
0.04 \\
0.06\end{array}$ & $\begin{array}{l}0.17 \\
0.40 \\
0.30 \\
0.17 \\
0.20\end{array}$ \\
\hline $\mathrm{D}$ & $\begin{array}{l}\text { Mon. } \\
\text { Tues. } \\
\text { Wed. } \\
\text { Thurs. } \\
\text { Fri. }\end{array}$ & $\begin{array}{l}2.1 \\
4.2 \\
4.0 \\
3.8 \\
2.5\end{array}$ & $\begin{array}{l}0.00^{b} \\
0.06 \\
0.01 \\
0.01 \\
0.01\end{array}$ & $\begin{array}{l}0.001 \\
0.06 \\
0.02 \\
0.01 \\
0.01\end{array}$ & $\begin{array}{r}3 \\
49 \\
13 \\
16 \\
13\end{array}$ & $\begin{array}{l}0.04 \\
0.07 \\
0.11 \\
0.05 \\
0.05\end{array}$ & $\begin{array}{l}0.04 \\
0.13 \\
0.12 \\
0.06 \\
0.06\end{array}$ \\
\hline $\mathbf{E}$ & $\begin{array}{l}\text { Mon. } \\
\text { Tues. } \\
\text { Wed. } \\
\text { Thurs. } \\
\text { Fri. }\end{array}$ & $\begin{array}{l}2.9 \\
7.1 \\
6.9 \\
7.9 \\
6.1\end{array}$ & $\begin{array}{l}0.00^{b} \\
0.01 \\
0.01 \\
0.00^{b} \\
0.01\end{array}$ & $\begin{array}{l}0.003 \\
0.02 \\
0.01 \\
0.01 \\
0.01\end{array}$ & $\begin{array}{l}7 \\
8 \\
3 \\
4 \\
5\end{array}$ & $\begin{array}{l}0.05 \\
0.24 \\
0.19 \\
0.16 \\
0.24\end{array}$ & $\begin{array}{l}0.05 \\
0.26 \\
0.20 \\
0.17 \\
0.25\end{array}$ \\
\hline \multirow[t]{2}{*}{$\mathbf{F}$} & $\begin{array}{l}\text { Mon. } \\
\text { Tues. } \\
\text { Wed. }\end{array}$ & 27 & $0.01^{\mathrm{c}}$ & $0.01 \mathrm{c}$ & 8 & $0.10^{c}$ & $0.11 \mathrm{c}$ \\
\hline & $\begin{array}{l}\text { Thurs. } \\
\text { Fri. }\end{array}$ & 27 & 0.004 & 0.003 & 16 & 0.02 & 0.02 \\
\hline
\end{tabular}

a The percentages were calculated from the exact figures.

b Below the detection limit.

c Morning values only.

ranged between 180 and $210 \mathrm{~min}$ and sample air volumes between 300 and $500 \mathrm{l}$.

Analysis. The total fume concentrations were determined from their weight and calculated in milligrams per cubic meter.

According to some earlier studies (13, 16), and also to our own observations, a part of metallic chromium oxidizes in the welding arc to hexavalent chromium compounds, some of which are watersoluble. Part of the chromium in the fumes is water-insoluble and probably consists of trivalent chromium compounds and metallic chromium (33). Therefore, the chromium contents in fume samples were de- termined separately for the water-soluble and the water-insoluble fraction.

For the determination of water-soluble chromium the samples were treated for 30 min at $80^{\circ} \mathrm{C}$ with $30 \mathrm{ml}$ of water. The mixture was filtered through a membrane filter and the solution was diluted with water to $50 \mathrm{ml}$. The water-soluble fraction was analyzed by atomic absorption spectrophotometry (AAS) and in addition with s-diphenylcarbazide (DPC) for hexavalent chromium.

The AAS determinations were made with a Perkin Elmer Model 403 spectrophotometer with an air-acetylene flame according to the manufacturer's manual. 
The detection limit was about $0.01 \mu \mathrm{g} \mathrm{Cr} /$ $\mathrm{ml}$, which corresponds to $1-2 \mu \mathrm{g} \mathrm{Cr} / \mathrm{m}^{3}$ in air samples of $300-5001$.

Hexavalent chromium forms a pink complex with DPC, and this reaction is very specific and sensitive $(20,30)$. For the colorimetric determinations, with DPC, 20$\mathrm{ml}$ portions were taken from the filtered water solutions, $1.25 \mathrm{ml}$ of sulfuric acid $(1+1)$ and $1 \mathrm{mg}$ of DPC in acetone were added, and the mixture was diluted to 50 $\mathrm{ml}$ with water. The absorbances were measured at $540 \mathrm{~nm}$. Potassium dichromate solutions were used as the colorimetric standards. The detection limit of the DPC method was about $0.05 \mu \mathrm{g} \mathrm{Cr}(\mathrm{VI}) / \mathrm{ml} \cdot \mathrm{cm}$, which corresponds to about $5 \mu \mathrm{g} \mathrm{Cr}$ (VI)/ $\mathrm{m}^{3}$ in air samples of $300-500 \mathrm{l}$.

The results of the chromium determinations made from the water-soluble fraction with AAS and the colorimetric DPC methods appear in table 1 . The results of the two agree well. Nearly all of the water-soluble chromium was hexavalent.

For the determination of the acid-soluble chromium compounds the water-insoluble residue from the fume samples was treated with a mixture of $10 \mathrm{ml}$ of concentrated nitric acid and $5 \mathrm{ml}$ of concentrated hydrochloric acid and evaporated carefully to dryness. The rest was diluted to $25 \mathrm{ml}$ with $5 \%$ nitric acid. The chromium concentrations were determined with AAS. The results are underestimates of the true chromium concentration because not all water-insoluble chromium compounds dissolve in a nitric acid/hydrochloric acid mixture. No corrections have been made in the present results since the undissolved proportion was unknown.

Interferences with the determination of hexavalent chromium with the DPC method. The reduction of hexavalent chromium to trivalent chromium that is caused by some agents, e.g., organic material, is possible during the collection and storage of fume samples and during the preparation of samples for analysis.

Some authors have reported on the reductive effect of cellulose ester membrane filters on hexavalent chromium (1). However, we did not find any significant reduction when we determined hexavalent chromium from the same fume samples immediately after sample collection and again after storage for two weeks. It is possible that a wet aerosol such as chromium acid mist may be reduced on filters, but not a dry aerosol such as welding fume.

In studying the possible reduction of hexavalent chromium during sample preparation, we treated and analyzed known amounts of potassium dichromate on cellulose ester membrane filters using the same procedure as for the fume samples. No reduction was found to be caused by the dissolving, heating and filtering operations.

Iron, nickel and molybdenum (VI) in high concentrations may interfere when hexavalent chromium is determined with the DPC method. Iron produces significant interference if the ratio $\mathrm{Cr}: \mathrm{Fe}=1: 5$ is exceeded. Nickel interferes only in over a thousandfold excess (20). In the sample solutions the concentrations of iron and nickel, determined with AAS, were low and under the levels of interference. Electrode wires for acid-resistant steel contain 2.3-2.5\% molybdenum. Molybdenum was not analyzed in the welding fume samples, but the possible interference was studied by the addition of ammonium molybdate to the potassium dichromate standard solutions. A hundredfold ratio of molybdenum to chromium produced no interference in the absorbance.

\section{Biological samples}

Sampling. Polyethylene bottles were used for the collection of the urine samples. All bottles were allowed to stand in a $10 \%$ Deconex solution overnight and were thereafter rinsed several times, first with tap water and finally with distilled water.

Special emphasis was placed on the avoidance of contamination. Before the sampling the subjects took off their work clothes and washed their hands. In addition, before the last sample of the day (at $1600)$ the subjects took a shower. The morning urine samples were collected at the workplace, and the subjects had been advised to urinate after waking up. Thus, this sample represented excretion after the night, not during it. 
Table 2. Results of the check on the reliability of the urine analysis.

\begin{tabular}{rcccc}
\hline $\begin{array}{l}\text { Spiked } \\
\text { sample }\end{array}$ & $\mathrm{N}$ & $\begin{array}{c}\text { Mean } \\
\text { recovery } \\
(\mu \mathrm{g} \mathrm{Cr} / 1)\end{array}$ & $\begin{array}{c}\text { Range } \\
(\mu \mathrm{g} \mathrm{Cr} / 1)\end{array}$ & $\mathrm{CV} \% \mathrm{a}$ \\
\hline $20 \mu \mathrm{g} \mathrm{Cr} / 1$ & 14 & 20.5 & $16.5-23.3$ & 9.7 \\
$100 \mu \mathrm{g} \mathrm{Cr} / 1$ & 21 & 101.9 & $92-109$ & 4.9 \\
\hline
\end{tabular}

a CV: Coefficient of variation.

The 5-ml venous blood samples were drawn into carefully washed, heparinized tubes.

Analysis. From the urine samples we first measured the specific gravity with a TS-meter (American Opticals) and took an aliquot for creatinine measurement. The creatinine concentrations were determined by the Jaffe reaction with the Technicon Auto Analyzer.

In the urine and blood chromium analyses we used electrothermal AAS (Perkin-Elmer 400, HGA 74). We made a $0.5 \mathrm{ml}+4.5 \mathrm{ml}$ dilution of the samples with Hamilton's Digital Diluter, and $20 \mu \mathrm{l}$ of these solutions were injected into the graphite tube by an auto sampler (PerkinElmer AS-1). The measuring conditions for the atomic absorption spectrophotometer were as follows: $\lambda 358 \mathrm{~nm}$, slit $0.7 \mathrm{~nm}$, hollow cathode lamp Cathodeon $7 \mathrm{~mA}$. Those for the heated graphite atomizer were: sample $20 \mu \mathrm{I}$, purge gas argon; dry $1,30 \mathrm{~s}, 115^{\circ} \mathrm{C}$; dry $2,30 \mathrm{~s}, 135^{\circ} \mathrm{C}$, the temperature program from 135 to $980^{\circ} \mathrm{C}$ in $45 \mathrm{~s}$, ash $20 \mathrm{~s}, 980^{\circ} \mathrm{C}$; atomize $11 \mathrm{~s}$, $2,500^{\circ} \mathrm{C}$.

The calibration of the method was performed with aqueous calibration standards of $2,5,10$, and $20 \mu \mathrm{g} \mathrm{Cr} / 1$ as potassium chromate prepared daily from a stock solution of $1,000 \mu \mathrm{g} / \mathrm{ml}$. Our calibration studies showed that a 1:10 diluted urine matrix had no effect on the absorption of chromium; thus simple aqueous calibration could be used.

The reliability of the method was checked with urine samples spiked with $20 \mu \mathrm{g} \mathrm{Cr} / \mathrm{I}$ and $100 \mu \mathrm{g} \mathrm{Cr} / \mathrm{l}$. The urine samples of each welder formed one series of analyses, and we repeated the measurement of these spiked samples three or four times within each series. The results are presented in table 2 .

The precision of the method was also checked by the analysis of duplicate samples. The coefficient of variation of the results of duplicate determinations was 4.9 $\%$ at the level $>100 \mu \mathrm{g} \mathrm{Cr} / 1$ and $6.5 \%$ at $<50 \mu \mathrm{g} \mathrm{Cr} / 1$. These imprecisions agree well with those obtained for the spiked urine samples. The practical detection limit of the method was $2 \mu \mathrm{g} \mathrm{Cr} / \mathrm{l}$.

\section{RESULTS}

The results of the air measurements are shown in table 1 . It can be seen that the total chromium component consists of a water-soluble and an acid-soluble (waterinsoluble) fraction. The total chromium concentration is probably an underestimate, however, because not all acid-soluble chromium compounds dissolve in the nitric acid/hydrochloric acid mixture used. The water-soluble fraction is mainly hexavalent and the acid-soluble fraction is probably trivalent, but part of it may also be other forms of chromium, e.g., metallic chromium.

The concentration of water-soluble chromium (hexavalent) in air exceeded the TLV of $0.05 \mathrm{mg} / \mathrm{m}^{3}$ almost daily for subjects $A, B$, and $C$. It exceeded the TLV on one day for subject $D$ but was constantly below the TLV for subject $\mathbf{E}$ and control subject $\mathrm{F}$.

From the total chromium concentration in air, the proportion of hexavalent chromium varied between 3 and $91 \%$ and was higher for the more exposed subjects. In regard to subjects $\mathrm{A}, \mathrm{B}$ and $\mathrm{C}$ the percentage of hexavalent chromium was almost constantly higher than $50 \%$. Subject $D$ welded only occasionally on Monday; consequently, his exposure was very low. His exposure was also quite low on other workdays, the highest value being on the order of the TLV. The low values of subject $\mathrm{E}$ can be explained by the fact that he did metal inert-gas (MIG) welding only. This mode of work seems to be associated with much lower exposure than welding with coated electrodes. Moreover, the proportion of water-soluble chromium seems to be lower in this type of welding. 

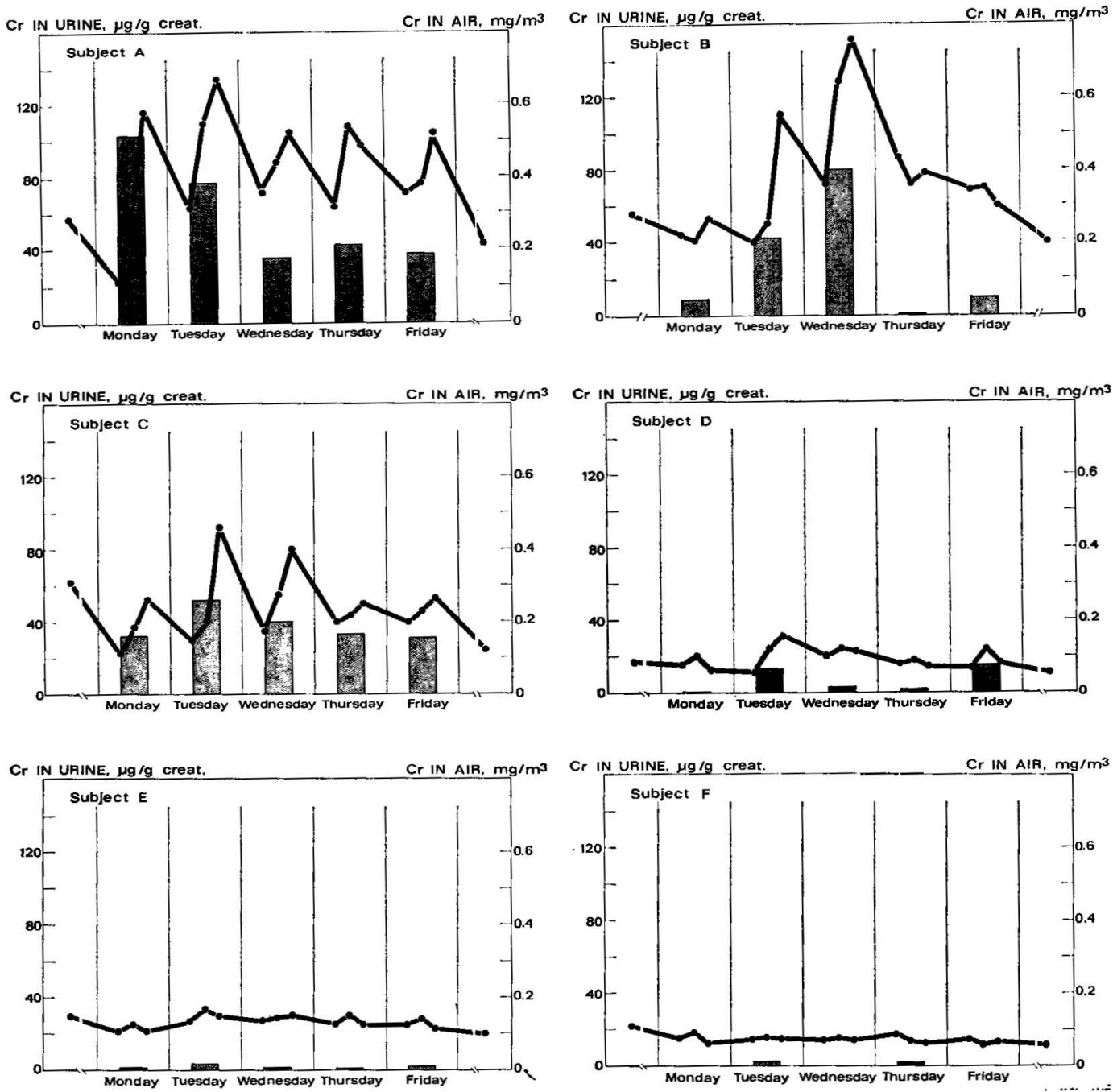

Fig. 1. Mean concentrations of water-solublechromium in workroom air (columns) and urine chromium concentrations (lines; the points re-present the times of sampling) of six welders during the study week.

The results of the measurements of chromium in the urine and air are shown in fig. 1 for each subject separately. Chromium in air in this figure means water-soluble chromium as measured by AAS. The chromium concentration in air that exceeded the TLV resulted in a rapid increase in urinary chromium excretion (subjects $\mathrm{A}-\mathrm{C}$ ). In subjects $\mathrm{D}$ and $\mathrm{E}$ the exposure was lower, and only when the concentration of chromium in air exceeded the TLV did an increase in the urinary excretion occur. The urinary chromium excretion of the control subject (F) remained constant during the study period. This level was higher however than the concentration found in occupationally nonexposed subjects such as laboratory personnel.

The increase in the excretion of chromium for the heavily exposed subjects (A - C) was observed already after some $3 \mathrm{~h}$ of welding, i.e., in the second urine sample of the day. The highest values were usually measured from the afternoon samples taken at the end of the workday. The 

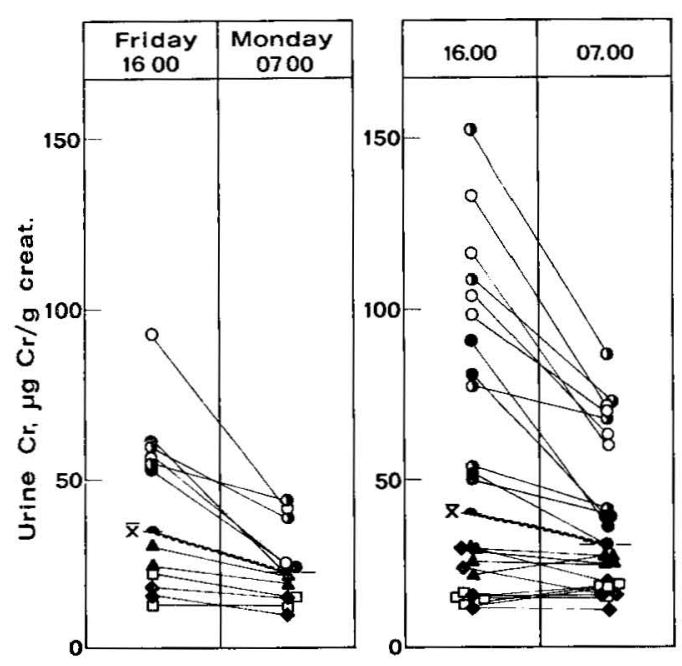

Fig. 2. Urinary excretion pattern of chromium during the weekend (left) and for two successive workdays (right).

morning values were low and suggested a rapid excretion during the night. The excretion pattern for the weekend and for two successive workdays is shown is fig. 2. In spite of the rapid excretion, a slight accumulation seems to have occurred during the week for the most exposed subjects since the morning values were a little higher towards the weekend than on Monday morning (fig. 1).

In order to study the relationship between the water soluble and insoluble chromium on one hand and the urinary excretion of chromium on the other, we compared the different air measurements (total chromium, water-soluble chromium and acid-soluble chromium) to urine concentrations (as measured values, values corrected to a specific gravity of 0.018 , and as values calculated per gram of excreted creatinine). Since the air sampling covered the total work time and its duration was about equal during the morning and afternoon, the arithmetic means of the morning and afternoon concentrations were considered to represent the time-weighted average concentration of the day accurately enough. The length of the sampling periods for welding fumes differed by a few minutes, but the difference was not considered to have any practical significance in the interpretation of the data.
In the calculation of the Pearson correlation coefficients all the values of each subject were considered as different points. This method has the drawback that exact levels of statistical significance cannot be determined for the coefficients because the calculations have been performed with data involving successive readings from the same subjects.

A good correlation was observed between water-soluble chromium in the air and the creatinine corrected urine afternoon values (fig. 3 ). The relationship improved when the morning values were subtracted from the afternoon ones, i.e.,

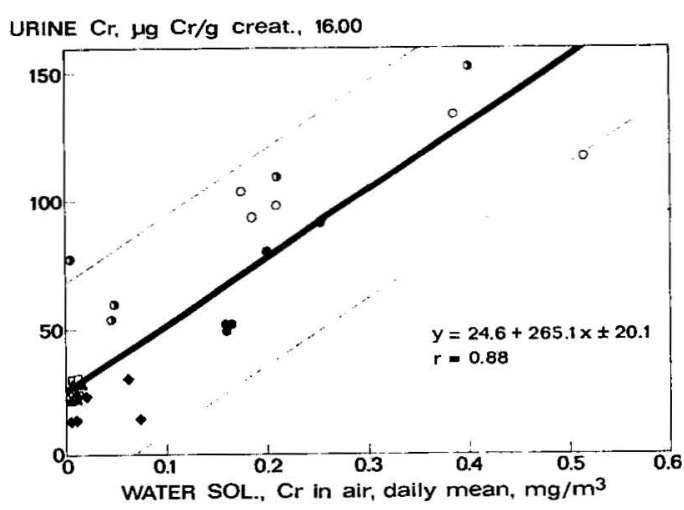

Fig. 3. Relationship between the water-soluble chromium concentration in the air and the creatinine-corrected urine concentration.

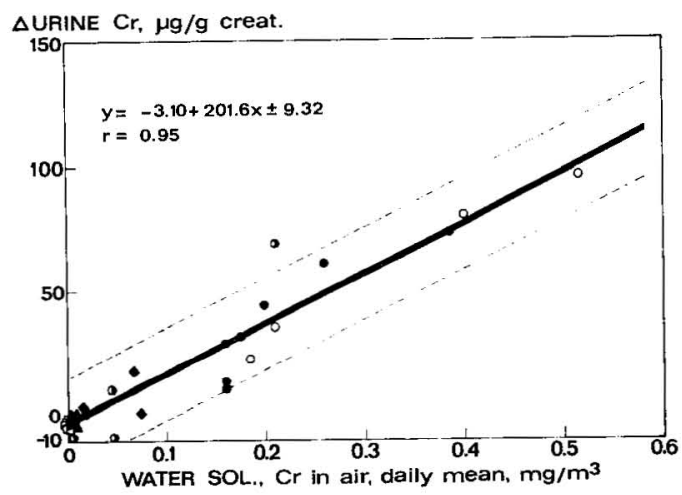

Fig. 4. Relationship between the water-soluble chromium concentration in the air and the workday increase in chromium excretion (creatinine-corrected) during the workday (difference between morning and afternoon measurements). 
Table 3. Relationship between various cromium $(\mathrm{Cr})$ measurements in workroom air and urine.

\begin{tabular}{|c|c|c|}
\hline Relationship & Equation & $\mathbf{r}$ \\
\hline $\begin{array}{l}\text { Water soluble } \mathrm{Cr} \text { in air, daily mean }\left(\mathrm{mg} / \mathrm{m}^{3}\right) \text {, } \\
\text { vs. urine } \mathrm{Cr}(\mu \mathrm{g} / \mathrm{g} \text { creatinine) at } 1600 \text { (fig. } 3 \text { ) }\end{array}$ & $\mathrm{y}=24.56+265.06 \mathrm{x} \pm 20.14$ & 0.88 \\
\hline $\begin{array}{l}\text { Water soluble } \mathrm{Cr} \text { in air, daily mean }\left(\mathrm{mg} / \mathrm{m}^{3}\right) \\
\text { vs. } \triangle \text { urine } \operatorname{Cr}(\mu \mathrm{g} / \mathrm{g} \text { creatinine) (fig. } 4)\end{array}$ & $y=-3.10+201.6 \times \pm 9.32$ & 0.95 \\
\hline $\begin{array}{l}\text { Water soluble } \mathrm{Cr} \text { in air, daily mean }\left(\mathrm{mg} / \mathrm{m}^{3}\right) \text {, } \\
\text { vs. urine } \mathrm{Cr}(\mu \mathrm{g} / \mathrm{l}) \text { at } 1600\end{array}$ & $y=24.29+486.22 \times \pm 42.22$ & 0.85 \\
\hline $\begin{array}{l}\text { Water soluble } \mathrm{Cr} \text { in air, daily mean }\left(\mathrm{mg} / \mathrm{m}^{3}\right) \\
\text { vs. } \triangle \text { urine } \mathrm{Cr}(\mu / \mathrm{l})\end{array}$ & $\mathrm{y}=-20.81+334.66 \mathrm{x} \pm 55.57$ & 0.65 \\
\hline $\begin{array}{l}\text { Water soluble } \mathrm{Cr} \text { in air, daily mean }\left(\mathrm{mg} / \mathrm{m}^{3}\right) \\
\text { vs. } \triangle \text { urine } \operatorname{Cr}(\mu \mathrm{g} / \mathrm{l}) \text {, corrected to specific } \\
\text { gravity }\end{array}$ & $y=-10.72+235.39 x \pm 23.37$ & 0.82 \\
\hline $\begin{array}{l}\text { Total } \mathrm{Cr} \text { in air, daily mean }\left(\mathrm{mg} / \mathrm{m}^{3}\right) \\
\text { vs. } \triangle \text { urine } \mathrm{Cr}(\mu \mathrm{g} / \mathrm{g} \text { creatinine })\end{array}$ & $y=-12.36+178.98 \times \pm 13.02$ & 0.90 \\
\hline $\begin{array}{l}\text { Water insoluble } \mathrm{Cr} \text { in air, daily mean }\left(\mathrm{mg} / \mathrm{m}^{3}\right) \text {, } \\
\text { vs. } \triangle \text { urine } \mathrm{Cr}(\mu \mathrm{g} / \mathrm{g} \text { creatinine })\end{array}$ & $y=15.40+50.72 \times \pm 29.67$ & 0.11 \\
\hline
\end{tabular}

the increase in urinary chromium excretion was compared with the chromium concentration in the air (fig. 4). From the regression lines it can be estimated that the afternoon urinary concentration corresponding to a mean daily chromium concentration of $0.05 \mathrm{mg} / \mathrm{m}^{3}$ (the present TLV) was about $33 \mu \mathrm{g} / \mathrm{g}$ creatinine and the corresponding increase in the urinary concentration during the workday was about $7 \mu \mathrm{g} / \mathrm{g}$ creatinine. The measured, uncorrected afternoon urinary concentration corresponding to $0.05 \mathrm{mg} / \mathrm{m}^{3}$ was about $38 \mu \mathrm{g} / 1$.

For the mutual comparison of the uncorrected and corrected urinary concentrations the increase in the excretion of chromium was compared to the watersoluble chromium concentration in the air (table 3). The correlation was best for the values corrected to creatinine, but it was also quite acceptable for the uncorrected values and the values corrected to specific gravity. The scatter around the regression line was the greatest for the uncorrected values, and the smallest for the values corrected to creatinine.

We studied the relationship between exposure to the different forms of chromium in air and the urinary excretion of chromium by comparing the increase in the creatinine-corrected chromium excretion during the workday with the concomitant exposure to various forms of chromium (table 3.). Water-soluble chromium showed the best correlation, followed by total chromium, while the concentration of water-insoluble chromium failed to show any significant correlation to the urine concentration.

The results of the blood chromium measurements are shown in table 4 . Those of the most heavily exposed subjects point toward a possible dose-effect relationship, but no conclusions can be drawn because of the small number of observations. Nevertheless, all the values were above the normal concentration of less than $0.5 \mu \mathrm{g} /$ $100 \mathrm{ml}$ that we have found in nonexposed workers in our laboratory.

Table 4. Blood chromium concentrations of six welders $(\mu \mathrm{g} / 100 \mathrm{ml})$.

\begin{tabular}{lccc}
\hline Subject & $\begin{array}{c}\text { Monday, } \\
0700\end{array}$ & $\begin{array}{c}\text { Tuesday, } \\
0700\end{array}$ & $\begin{array}{c}\text { Tuesday, } \\
1600\end{array}$ \\
\hline & & & \\
A & 2.3 & 3.0 & 4.5 \\
B & 3.5 & 4.0 & 5.1 \\
C & 3.1 & 3.8 & 3.9 \\
D & 1.3 & 1.1 & 1.3 \\
E & 3.8 & 3.1 & 3.5 \\
F (control) & 1.9 & 1.9 & 1.9 \\
\hline
\end{tabular}




\section{DISCUSSION}

In our study welding high alloy $\mathrm{Cr}-\mathrm{Ni}$ steel caused unacceptably high exposure to chromium for some of the subjects. The level of exposure was comparable to that recently reported by Vorpahl et al. (35) in connection with the welding of highly alloyed $\mathrm{Ni}-\mathrm{Cr}$ steel.

The symptoms of the welders of our study were relatively minor. Generally the irritation symptoms associated with welding can be attributed to fluoride exposure, which is common when basic coated electrodes are used. Our subjects used rutilecoated electrodes however, and, except for the control subject, none of them were exposed to fluoride. Thus the chromium exposure may have caused their symptoms.

It should be emphasized that high levels of exposure to chromium were measured only during welding with coated electrodes. The exposure level during MIG welding was much lower (subject E). Since the exposure of welders using coated electrodes was found to be unacceptably high, the enterprise for which the welders worked has already taken measures to diminish exposure and is installing a more effective local exhaust system. The ultimate solution of the problem would be a new building with facilities for MIG welding as the main type of welding method.

The MIG welding caused the lowest total exposure and, moreover, the proportion of hexavalent chromium was remarkably low. Thus the health hazard caused by exposure to chromium during welding can be considerably reduced if welding with coated electrodes is replaced by MIG welding.

The analysis of the welding fumes showed that only part of the chromium to which welders are exposed is in the biologically more active hexavalent form. The large variation in the proportion of hexavalent chromium of the total chromium indicates that the latter cannot. be reliably used for the assessment of exposure to hexavalent chromium and the analysis of the water-soluble fraction is essential. Otherwise completely misleading conclusions may be drawn.

The urinary concentration of chromium reflected the exposure to water-soluble chromium (hexavalent) well, but no cor- relation seemed to exist for the waterinsoluble (trivalent) form. This finding agrees with experimental results (5) indicating that very little trivalent chromium is absorbed from the lungs to the blood stream. Korallus et al. (21) reported an increased excretion of chromium in workers exposed to trivalent chromium as compared to nonexposed controls, but he did not report any correlation to air chromium concentration.

Thus, provided that the exposure is indeed to hexavalent chromium, measuring the urinary chromium concentration is a good method for estimating individual short-term exposure. Unfortunately, this method does not seem to be applicable to low levels of exposure. Below the current TLV there was no concomitant elevation in the excretion of chromium. Nevertheless, the baseline concentrations of all the welders, including the control subject, were higher than the levels measured in occupationally nonexposed persons, possibly because of chronic exposure. The excretion pattern during high short-term exposure indicates that excretion occurs rapidly (fig. 2). In animal experiments a three-phase excretion pattern has been demonstrated for trivalent chromium (27) with half-times of $0.5,5.9$ and 83.4 days, respectively. Whether this applies to man is not known, but it is probable that the excretion pattern found in our present study represents a rapid compartment, the increased baseline excretion being an indication of increased chromium body burden, which would have a longer half-time.

When urine samples are used, their general limitations should be kept in mind $(10,28)$. Our results agree with the opinion of Lauwerys (23) that correction to creatinine should be preferred to correction to specific weight.

The increase in chromium excretion during the workday seems to reflect exposure better than the measurement of afternoon urine concentration only. Nevertheless, the difference is so small that, for practical purposes, measurement of chromium excretion from spot urine samples at the end of the workday can be recommended for routine testing.

As early as 1955 Vigliani and Zurlo (34) suggested that a urinary concentration of $50 \mu \mathrm{g} / 1$ would correspond to an air chromic 
acid concentration of $0.05 \mathrm{mg} / \mathrm{m}^{3}$. Franzen et al. (12) proposed a urine concentration of $25 \mu \mathrm{g} / 1$ as an indication of a need for further studies. In the guidelines for the periodical medical examinations of the Federal German Republic a urine concentration range of $20-30 \mu \mathrm{g} / 1$ is given as tolerable (37). Recently, Gylseth et al. (15) suggested that a concentration of $40-50$ $\mu \mathrm{g} / 1$ would correspond to the TLV of 0.05 $\mathrm{mg} / \mathrm{m}^{3}$. Their conclusion was based on measurements from a few subjects only, and they used uncorrected urinary concentrations.

According to our data, a concentration of about $38 \mu \mathrm{g} / 1$ (uncorrected value) corresponded to the air concentration of 0.05 $\mathrm{mg} / \mathrm{m}^{3}$. When correction to creatinine was used, a concentration of about $33 \mu \mathrm{g} / \mathrm{g}$ creatinine corresponded to $0.05 \mathrm{mg} / \mathrm{m}^{3}$ of chromium in air (fig. 3). Thus our results agree well with the earlier mentioned figures. It seems that, if the urine concentration is below about $30 \mu \mathrm{g} / \mathrm{g}$ of creatinine, the air concentration of $0.05 \mathrm{mg} / \mathrm{m}^{3}$ is not exceeded. It should be emphasized, however, that this observation applies to short-term exposure only. The relationship between chronic exposure and urinary chromium excretion is more complex and relatively unknown.

Under optimal conditions, the relationship should be known between a biological exposure test and both exposure and effect. This situation is, unfortunately, very rare. Strictly speaking, biological monitoring in connection with exposure to lead is the only pattern which meets this criterion (17).

The symptoms in connection with exposure to chromium have been extensively studied. However, their relation to the chromium concentration in air needs further investigation $(8,32)$. Even more obscure from the point of view of a doseeffect or dose-response relationship is the connection between exposure to chromium and lung cancer $(8,32)$. Thus the relationship between exposure and the effect of chromium is far from solved today and, consequently, so is the relationship between urine concentrations and biological effects.

Basing biological limit values on air TLVs is always a preposterous process.
For chromium it is even more ambiguous since the air TLV is uncertain. Thus, the limitations of this approach should be kept in mind when the suggested biological limits are considered. If exposure to chromium is allowed at all, it should be kept so low that the urinary excretion of chromium does not increase. The suggested concentration of $30 \mu \mathrm{g} / \mathrm{g}$ creatinine seems to meet this criterion for short-term exposure. Should the TLV be lowered for "carcinogenic chromium," as suggested by the National Institute for Occupational Safety and Health in the United States (30), urinary determinations would probably be too insensitive for the surveillance of exposure.

\section{ACKNOWLEDGMENTS}

We wish to thank Ms. M. L. Dahlberg, Ms. A. Grundström and Mr. R. Liukkonen for their skillful technical assistance.

We are indebted to the A. Ahlström Company for the possibility of conducting this study. Without the cooperation of both the workers and the management this work would not have been feasible.

\section{REFERENCES}

1. ABELL, M. T. and CARLBERG, J. R. A simple reliable method for the determination of airborne hexavalent chromium. $A m$. ind. hyg. assoc. j. 35 (1974) 229-233.

2. ADAMS, R. M. Occupational contact dermatitis. J. B. Lippincott Company, Philadelphia, Pa., and Toronto 1969, pp. 159161.

3. BAETJER, A. M. Pulmonary carcinoma in chromate workers: I. A review of the literature and report of cases. Arch. ind. hyg. occup. med. 2 (1950) 487-504.

4. BAETJER, A. M. Pulmonary carcinoma in chromate workers: II. Incidence on basis of hospital records. Arch. ind. hyg. occup. med. 2 (1950) 487-504.

5. BAETJER, A. M., DAMRON, C. and BUDACZ, V. The distribution and retention of chromium in men and animals. Arch. ind. health 20 (1959) 136-150.

6. BORGHETTI, A., FRANCHINI, I., MUTTI, A. and PASETTI, G. C. Indices rénaux d'exposition aique et d'imprégnation chronique par le chrome. In: XVIII international congress on occupational health, Brigh- 
ton, England 14-19 Sept. 1975, pp. 325326.

7. BROWNING, E. Toxicity of industrial metals. Butterworths, London 1969, pp. 199-131.

8. COMMITTEE ON BIOLOGICAL EFFECTS OF ATMOSPHERIC POLLUTANTS, DIVISION OF MEDICAL SCIENCES, NATIONAL RESEARCH COUNCIL. Chromium. National Academy of Sciences, Washington, D. C. 1974.155 p.

9. EDMUNDSON, W. F. Chrome ulcers of the skin and nasal septum and their relation to patch testing. J. invest. dermatol. 17 (1951) $17-19$.

10. ELKINS, H. B. and PAGNOTTO, L. D. Concentration adjustments in urinalysis. $A m$. ind. hyg. assoc. $j .35$ (1974) 559-565.

11. ENTERLINE, P. Respiratory cancer among chromate workers. J. occup. med. 16 (1974) $523-526$.

12. FRANZEN, E., POHLE, R. and KNOBLICH, K. Arbeitshygienische Untersuchungen in Betrieben der Galvanotechnik III. Chrom im Urin. Z. Gesamte Hyg. Ihre Grenzgeb. 16 (1970) 657-661.

13. FREGERT, S. and OUVRUM, P. Chromate in welding fumes with special reference to contact dermatitis. Acta derm. venereol. 43 (1963) $119-124$.

14. FREGERT, S. and RORSMAN, H. Allergy to trivalent chromium. Arch. dermatol. 90 (1964) 4-6.

15. GYLSETH, B., GUNDERSEN, N. and LANGARD, S. Evaluation of chromium exposure based on a simplified method for urinary chromium determination. Scand.$j$. work environ. \& health 3 (1977) $28-31$.

16. HANSLIAN, L. Výskyt šestimocného chrómu $\mathrm{v}$ prúmyslových podminkách [Occurrence of hexavalent chromium in industrial conditions]. Prakov. lék. 21 (1969) 142-145. (English summary)

17. HERNBERG, S. Lead. In: C. ZENZ (ed.), Occupational medicine. Year Book Medical Publishers, Inc., Chicago 1975, pp. $715-769$.

18. HERNBERG, $S$. Incidence of cancer in population with exceptional exposure to metals. In: Origins of human cancer 1977, pp. 65-70. (In press)

19. KNOBLICH, K., RENKER, U., KLEINE, D. and FRANZEN, E. Arbeitshygienische Untersuchungen in Betrieben der Galvanotechnik IV. Arbeitsmedizin. Z. Gesamte Hyg. Ihre Grenzgeb. 16 (1970) 742-748.

20. KOCH, G. and KOCH-DEDIC, G. Handbuch der Spurenanalyse. Springer-Verlag, Berlin 1964, pp. 480-495.

21. KORALLUS, U., EHLICHER, H. and WÜSTEFELD, E. Dreiwertige Chromverbidungen. Ergebnisse einer arbeitsmedizinischen Untersuchung. Arbeitsmed. Sozialmed. Präventivmed. 9 (1974) 248-252.

22. LANGARD, S. and NORSETH, T. A cohort study of bronchial carcinomas in workers producing chromate pigments. $\mathrm{Br}$. j. ind. med. 32 (1975) $62-65$.

23. LAUWERYS, R. Biological criteria for selected industrial toxic chemicals: A review. Scand. j. work environ. \& health 1 (1975) $139-172$.

24. LEVIN, H. M., BRUNNER, M. J. and RATTNER, H. Lithographer's dermatitis. J. am. med assoc. 169 (1959) 566-569.

25. LUMIO, J. Om skador i de övre andningsvägarna hos förkromare. Nord. hyg. tidskr. 516 (1963) 86-91.

26. MANCUSO, T. F. Occupational cancer and other health hazards in a chromate plant: A medical appraisal: II. clinical and toxicologic aspects. Ind. med. surg. 20 (1951) $393-407$.

27. MERTZ, W., ROGINSKI, E. E. and REBA, R. C. Biological activity and fate of trace quantities of intravenous chromium (III) in the rat. Am. j. physiol. 209 (1965) 489-494.

28. MOLYNEUX, INI. K. B. Use of single urine samples for the assessment of lead absorption. Br. j. ind. med. 21 (1964) 203-209.

29. MORRIS, G. E. "Chrome" dermatitis: A study of the chemistry of shoe leather with particular reference to basic chromic sulfate. Arch. dermatol. 78 (1958) 612-618.

30. NATIONAL INSTITUTE FOR OCCUPATIONAL SAFETY AND HEALTH. Criteria for a recommended standard... Occupational exposure to chromium (VI). U.S. Government Printing Office, Washington, D.C. 1975.200 p.

31. NORSETH, T. Chromium and its compounds. In: C. ZENZ (ed.), Occupational medicine. Year Book Medical Publishers, Inc., Chicago, Ill. 1975, pp. 644-649.

32. SAMITZ, M. H. and KATZ, S. A study of the chemical reactions between chromium and skin. J. invest. dermatol. 38 (1964) 3543.

33. STERN, R. M. A chemical, physical and biological assay of welding fumes. In: The Hungarian-Finnish-Scandinavian symposium on industrial dust problems. Institute of Occupational Health, Helsinki 1977, pp. $44-58$.

34. VIGLIANI, E. G. and ZURLO, N. Erfahrungen der Clinica del Lavoro mit einigen maximalen Arbeitsplatzkonzentrationen (MAK) von Industriegiften. Arch. Gewerbepathol. Gewerbehyg. 13 (1955) 528-534.

35. VORPAHL, K. W., JORDAN, P. T. and MATHEWS, E. J. Chrome alloy welding fume study. Am. ind. hyg. assoc. j. 37 (1976) $566-569$.

36. WOHLENBERG, H. and LENHARD, J. Die Chrom-Enteropathie. Ihre differentialdiagnostische und sozialmedizinische Bedeutung. Dtsch Med. Wochenschr. 95 (1970) $1224-1226$.

37. -. Berufsgenossenschaftliche Grundsätze für Arbeitsmedizinische Vorsorgeuntersuchungen, Gefährdung durch Chrom VI - Verbindungen. Arbeitsmed. Sozialmed. Präventivmed. 9 (1974) 17-19. 